\title{
BIOMARKERS OF GENOTOXICITY IN CAR PAINTING WORKERS
}

\author{
$\mathcal{B Y}$ \\ Jaklin Fekri Zaher, Ghada Attia Ishak, Ashraf Mahmoud Abdo, \\ Enas Kamal abd El-Azeem and Saad Mansour Hassan El-Sekelly* \\ Departments of Forensic Medicine and Clinical Toxicology and \\ *Biochemistry, Faculty of Medicine, El -Minia University, Egypt
}

\begin{abstract}
This work was done to determine the biomarkers of genetic damage as a result of occupational exposure to many dangerous chemicals in car painting workshops. Fifty subjects were included in this work. They were divided into two groups; group $I(n=25)$ : workers exposed to painting substances in car painting workshops and group II $(n=25)$ : non exposed workers from the administrative staff in the same car painting workshops, who serves as a control. Blood samples were withdrawn and examined for chromosomal aberrations; lymphocyte micronucleus frequency and alkaline single cell gel electrophoresis (comet assay) were performed. The results revealed significant increases in chromosomal aberrations (breaks and gaps), micronuclei frequency, and size of the comet tail and damage index of comet assay in the exposed group as compared with non-exposed group. Also, cells were scored visually in the comet assay into five classes from undamaged - 0 to maximally damaged-4. In conclusion, the study concluded that occupational exposure to automobile spray painting substances leads to an increased risk of genetic damage. Also, chromosomal analysis to detect chromosomal aberrations, lymphocyte micronucleus assay to detect frequency of micronuclei and alkaline single cell gel electrophoresis (comet assay) to detect DNA break are useful biomarkers for assessing the genotoxicity in exposed workers in car painting workshops.
\end{abstract}

\section{INTRODUCTION}

Automobile spray painting is among jobs which are likely to result in exposure to an extensive variety of hazardous chemicals that are potentially genotoxic such as organic solvents (tolune, xylene, heptane and acetate), several types of resins (urethane, isocyanate and thinnar) which contains benzene and heavy metals(lead, cadmium and chromium) which are major components of paint pigments that contain lead chromate, lead oxide, cadmium yellow, chrome yellow and orange (Banjong et al., 2005).

Automobile paints are sprayed and suspended in the atmosphere long enough to be inhaled by paint sprayers. Moreover, the application or removal of paints was occasionally performed without protection by masks or gloves. Chronic occupa- 
tional exposure to such derivatives is considered to possess genotoxic risk and may contribute to the development of many neoplasia, through mechanisms that involve chromosomal changes (Pinto et al., 2000).

Genotoxicity biomarkers have received considerable interest as tools by which damages to DNA or to chromosomes can be identified. Panels of biomarkers are used for detecting human genotoxic exposure effects (Pitarque et al., 2002).

The conventional cytogenetic studies for evaluating genetic damage include chromosomal aberration (CA), micronucleus (MN) assay and sister chromatid exchanges (SCE). A high frequency of chromosomal aberrations is predictive of an increased cancer risk, probably as a manifestation of genetic instability (Norppa, 2004).

Chromosomal aberrations (CA) may be chromatid -type or chromosome- type, gaps, breaks, breaks plus exchanges and total type aberrations (Tuimala et al., 2005).

Micronuclei (MN) derive from chromosomal fragment and whole chromosomes lagging behind in anaphase. MN assay can be used to show both clastogenic and aneugenic effects. It is a good indicator of chromosome mutations. It can be used as an endogenous dosimeter in tissues that are specific targets of genotoxic agents where carcinomas will develop (Martino et al., 2002).

Alkaline single cell gel electrophoresis (comet assay) is a newer technique for measuring DNA breaks in individual human cells. This assay is extremely used in biology, medicine and toxicology due to capacity and sensitivity in demonstrating DNA breaks, both single and double strands breaks and alkali- labile sites (Nersesyan, 2005).

The aim of this work was to determine the genotoxic effects of occupational exposure to hazardous chemical in car painters through chromosomal analysis, micronucleus test and comet assay parameters.

\section{SUBJECTS AND METHODS}

\section{A-Subjects:}

This work was done in different automobile body repair shops in El-Minia and Cairo cities that had no standard spraying room. Fifty subjects were included in this work. They were divided into two groups; group I ( $n=25$ ) includes technical workers exposed to painting substances in car painting job for at least one year and group $\Pi(\mathrm{n}=25)$ : includes non-exposed subjects from the administrative staff who serve as a control group. 
The exposed and control groups were matched in the age and duration of service. All the individuals were males, ranged from 20 to 50 years old. All participants signed an informed written consent form and participated in this work only once.

All individuals who agreed to participate in this work were healthy and answered a detailed questionnaire about occupational exposure, use of drugs or alcohol, repeated virus illnesses and any previous radiological examinations to exclude exposure to other potential sources of genotoxics. Only non smokers were chosen. Some of individuals studied were ex-smokers one year ago or more.

\section{B- Methods:}

\section{Chromosomal analysis:}

A venous blood sample was drawn aseptically from each subject (about $5 \mathrm{ml}$ in a heparinized disposable syringe). Then, 0.5 of whole blood was put in a sterile tube containing the media (1vial of phytohemagglutinin was mixed to $100 \mathrm{ml}$ of culture media). Then, $25 \mathrm{ml}$ of fetal calf serum (FCS) was added. The mixture was divided into sterile centrifuge culture tubes, $5 \mathrm{ml}$ in each tube. The tubes were shaken and put in the incubator in an oblique position for 72 hours. Two hours before the end of the incubation, $0.1 \mathrm{ml}$ colchicine $(0.05 \%)$ was added to block the dividing cells in metaphase and contracts the chromosomes making them to appear more distinctive.

Lastly, cells were harvested and slides were stained with Giemsa stain diluted with $\mathrm{PH} 6.8$ phosphate buffer and $46 \mathrm{ml}$ distilled water. Each slide was examined under light microscope to detect metaphases according to Liou et al., (1999).

\section{Lymphocyte Micronucleus Assay:}

Lymphocytes were isolated from $5 \mathrm{ml}$ of whole blood obtained from the persons. Centrifugation was done and washed twice with $\mathrm{PH} 7.2$ phosphate buffered saline. Cells were cultured at $37^{\circ} \mathrm{C}$ for 72 hours in $5 \mathrm{ml}$ chromosome medium that contains $10 \mathrm{ml}$ phytohaemagglutinin. Then, cells were treated with hypotonic saline for 2-3 minutes, fixed three times in methanol/acetic acid (5:1) solution, and harvested on slides. The slides were dried and stained for 15 minutes in diamidino phenyl indole (DAPI). 500 binucleate cells were examined for each subject with a light microscope using coded slides. Only cells which were non- fragmented, nonaccumulated, and contained intact nuclei were examined.

Criteria used for Micronuclei detection were as follow: less than one third in diameter of the main nucleus, on the same plane of focus, have the same color, texture and refraction as the main nucleus, have a smooth oval or round shape and 
clearly separated from the main nucleus. Questionable micronuclei were disregarded. The values were presented as the number of micronuclei per 500 binucleated cells according to Martino et al., (2003).

\section{Alkaline comet assay:}

The alkaline comet assay was conducted as described by Szyfter et al. (2004). Briefly, Five microliters $(\mu \mathrm{l})$ of blood were mixed with $70 \mu$ of $1 \%$ low melting point agarose in the RPMI 1640 medium at $37^{\circ} \mathrm{C}$. The mixture was pipetted onto microscope slides previously pre-coated with a layer of $1 \%$ normal agarose. The slides were immersed in lysis solution $(2.5 \mathrm{mM}$ $\mathrm{NaCl}, 0.1 \mathrm{mM}$ EDTA (ethylene diamine tetra acetate), $10 \mathrm{mM}$ tris, $1 \%$ of freshly added Triton X-100, PH 10) for 1 hour to remove proteins. The slides were then placed in a horizontal electrophoretic tank in cold buffer $(0.3 \mathrm{mM} \mathrm{NaOH}, 1 \mathrm{mM}$ EDTA, PH 13) for 40 minutes to allow DNA unwinding. The electrophoresis was carried out in the same solution for 30 minutes after electrophoresis, slides were removed from the tank and immersed in neutralization buffer $(0.4 \mathrm{M}$ tris, $\mathrm{PH} 7.5)$, stained with Ethidium bromide ( $2 \mu \mathrm{g} \mathrm{ml}-1$ in distilled water) and viewed in an Olympus fluorescence microscope. 100 cells were counted per sample.

Both qualitative and quantitative assessment of DNA damage was carried out. Images from each slide were scored visu- ally as belong to one of five classes of DNA damage, from score zero (round images) to score 4 (most of DNA had migrated from the head to the tail). An average level of DNA damage was calculated by multiplying the number of cells in a class by the score number. A total of 100 cells were scored. Thus, the level of DNA damage ranges from score zero (undamaged) to score 400 (highly damaged).

The statistical analysis was performed using hypothesis test (test of proportion) for chromosomal aberrations and student's t-test for micronucleus test and comet assay parameters. A value at $p$ $<0.05$ was considered significant.

\section{RESULTS}

\section{Chromosomal analysis:}

Chromosomal analysis from group II (control group) showed normal chromosomal pattern (Fig. 1).

As regard the exposed group (Group I), 20 cases $(80 \%)$ were found to have chromosomal breaks as compared with 6 cases only $(24 \%)$ in control group (Group II) as shown in fig. (2) and table (1). The difference was significant where $Z=3.96$ and $\mathrm{P}=0.0001$.

The present work also showed that there were 18 cases $(72 \%)$ in group I (exposed) found to have chromatid gaps as 
compared with 3 cases only (12\%) in group II (control) as shown in fig. (3) and table (2). The difference was significant ( $Z=4.29$ \& $P=0.0001)$.

Fig. (4) is a histogram demonstrating a comparison between the incidence of breaks and gaps among the exposed and control groups.

\section{Lymphocyte micronucleus assay:}

The results of this work showed that the number of micronucleated lymphocytes was higher in group I (exposed) (mean $=15.16, \mathrm{SD} \pm 4.45)$ than in group II (control) $($ mean $=2.44 \& S D \pm 1.99)$. The difference was significant $(\mathrm{T}=13.04 \& \mathrm{P}=$ 0.0001 ) as shown in table (3).

Fig. (5) is a histogram demonstrating a comparison of the mean number of micronucleated cells between group I (exposed) and group II (control).

\section{Alkaline comet assay:}

DNA damage was analysed qualitatively. Cells with damaged DNA form a comet, consisting of a head (nuclear matrix) and a tail, formed by DNA fragments. Cells were scored visually as belong to one of five classes, from class 0 (undamaged) (Fig. 6), class 1 (Fig. 7), class 2 (Fig. 8), class 3 (Fig. 9) and class 4 (maximum damage) (Fig. 10).

Quantitatively, size of the comet tail measured in $\mu \mathrm{m}$ of 100 cells analyzed for each individual of group I (exposed) was (mean $=36.38 \& S D \pm 9.34)$ higher than group II (control) (mean $=26.25 \& \mathrm{SD} \pm$ 8.51). The difference was significant ( $\mathrm{T}=$ $1.74 \& \mathrm{P}=0.003$ ) as shown in table (4).

Fig. (11) shows a histogram illustrating a comparison between group I and group II regarding size of the comet tail.

The damage index in 100 cells analyzed for each individual of group I (exposed) was (mean $=18.08 \& \mathrm{SD} \pm 4.36$ ) higher than group II (control) (mean $=2.23 \& \mathrm{SD}$ $\pm 1.71)$. The difference was significant $(\mathrm{T}=$ $16.9 \& P=0.001)$ as shown in table (5).

Mean of the damage index in both group I (exposed) and group II (control) was demonstrated in fig. (12).

\section{DISCUSSION}

Health suffers the influence of inherited, nutritional and environmental factors. Populations that are intensely exposed to chemical substances are at risk of mutations, cancer and congenital defects. Occupational agents can induce several types of cancer such as larynx, skin, urinary tract, pancreas cancers and leukemias (Martino et al., 2002).

There has been a great interest in developing rapid and simple tests to identify 
the effects of exposure to occupational agents that can affect the health of the exposed individuals due to DNA damage. Cytogenetic biomarkers are useful as damages to DNA or to chromosomes resulting from exposure can be identified (Nersesyan, 2005).

All subjects chosen in this work were non smokers to exclude the effects of this common confounder that is known to affect chromosomal aberration rates. Some individuals were ex-smokers one year ago or more as no significant effects of previous smoking on the chromosome damage could be observed by (Knudsen et al., 1999).

As regard chromosomal analysis, this work revealed that carpainters have significant chromosomal breaks and chromatid gaps compared to non exposed individuals (control). This is consistent with results of both Silva and Santos, (1996) and Testa et al., (2005) who found that the exposed group of automobile painters had a significant $(P<0.001)$ higher frequencies of chromosomal aberrations (CA) both chromosome- and chromatid- types\}.

Nearby results were found by Knudsen et al., (1999) who reported that long term exposure to urban air pollution induces a significantly higher frequency of cells with chromosomal aberrations. This finding was also recorded by Celi and
Akbas, (2005) who reported that exposed workers in gasoline stations have a significantly $(P<0.01)$ higher chromosomal aberrations compared with control individuals.

Chromatid gaps are the result of unrepaired lesions in DNA. Gaps have both an upper size limit (the width of two chromatids) and a lower size limit (the width of a chromatid) to avoid recording any small unstained area in chromosomes as gaps (Liou et al., 1999).

The frequency of chromosomal aberrations (CA) measured in peripheral lymphocytes provides informations about the cumulative effects of combined exposure to carcinogens, which is highly associated with increased cancer risk (Hegmar et al., 1998). This finding was also recorded by Tuimala et al., (2005) who stated that elevated levels of chromosomal aberrations (CA) in peripheral blood lymphocytes (widely used as a cytogenetic biomarker of genotoxic effects) have been linked to cancer predisposition.

Concerning lymphocyte micronucleus (MN) assay, this work demonstrated that the exposed carpainters had significant higher number of micronucleated lymphocytes than the non exposed persons (control). This was meeting with Martino et al. (2002 \& 2003) who used the micronucleus test $(\mathrm{MN})$ to detect and 
quantify the occupational genotoxicity in workers of carpainters and battery repair garages.

Moreover, Testa et al. (2005) found a combined significant $(\mathrm{P}<0.001)$ higher frequencies of chromosomal aberrations (CA), lymphocyte micronuclei (MN) and sister chromatid exchanges (SCE) in automobile painters. This was compatible with results of this work.

Similarly, Pitarque et al. (2002) used lymphocyte micronucleus (MN) and sister chromatid exchange (SCE) as biomarkers of genotoxic exposure and effect in shoe factory workers exposed to solvents as simpler alternative to chromosomal analysis.

Lymphocyte micronucleus (MN) assay presents great advantages over other techniques: it is applicable on interphase preparations, is a good indicator of chromosome mutations, is not invasive and has a low cost. Its sensitivity is compared to the analysis of chromatid breaks and exchanges (Martino et al., 2003).

Micronuclei harbouring chromosomes can be distinguished from those harbouring acentric fragments by the presence of a centromere (Norppa and Falck, 2003).

Regarding the comet assay, this work revealed that both size of the comet tail (measured in $\mu \mathrm{m}$ of 100 cells analysed for each individual) and damage index in 100 cells analysed for each individual of the exposed group were significantly higher than control. This was in line with results of Martino et al., (2003) who stated that the damage index is a very sensitive parameter and found significant differences in both the damage index (about 7 times in carpainters) and size of the comet tail in carpainters and battery renovation workers. They identified tail length as the distance of DNA migration from the body of the nuclear core and it is used to evaluate the extent of DNA damage.

Also, Fucks et al. (1996) found a significant increase in DNA strand breaks and alkali-labile sites in spray painters after a week's work. However, that DNA damage seemed to be reversible.

In this work, cells were also scored visually into five classes, according to tail size (from undamaged-0, to maximally damaged-4). This agree with Klaude et al., (1996) who assigned a value to each comet according to each class.

Nersesyan, (2005) stated that comet assay is a rapid, non invasive and sensitive technique to measure sites sensitive to basic PH (alkali-labile) and DNA breaks. The alkaline conditions cause the separation of the paired bases enabling the detection of simple chain ruptures . 
The result of this study revealed that positive results in $\mathrm{MN}$ assay corresponds to positive results in the comet assay which means that the defects are many. This finding doesn't agree with Martino et al., (2003) who reported that positive results in the comet assay don't always correspond to positive results in $\mathrm{MN}$ test as they attributed this to the small period of exposure to genotoxic agents which result in small defects.

Testa et al., (2005) stated that the positives in the comet and MN tests are due to different mechanisms; the $\mathrm{MN}$ test detects injuries that survives at least one mitotic cycle, while the comet assay identifies alkali-labile sites. Consequently, the use of both MN and comet tests is suggested.

\section{Conclusion and Recommendation:}

This work makes it clear that car painters are presented with DNA damage as evidenced by increases in chromosornal aberrations, frequency of cells with micronuclei and comet assay parameters. This is due to substances to which they were exposed at work. Thus, car painters represent a risk group because chronic occupational exposure to such derivatives considered to posses a genotoxic risk. So, it is recommended that they should be followed up with a judicious periodic examinations using cytogenetic biomarkers.

Genotoxic evaluation is necessary to guarantee environmental quality and uccupational health as well as to orient workers to help in reducing genetic damage and the risk of serious illness.

There is an urgent need to identify the genotoxic chemicals in the occupational environment of car painters and to develop satisfactory safety measures. 
Zaher, et al...

Table (1): Incidence and comparison of chromosomal breaks in groups I \& II.

\begin{tabular}{|c|c|c|}
\hline Groups & No breaks & Breaks \\
\hline Group I ( exposed) & $5(20 \%)$ & $20(80 \%)$ \\
\hline Group II ( control) & $19(76 \%)$ & $6(24 \%)$ \\
\hline Z & \multicolumn{2}{|c|}{3.96} \\
\hline P & $0.0001^{*}$ \\
\hline
\end{tabular}

$\mathrm{P}<0.05$ significant*.

Table (2): Incidence and comparison of chromatid gaps in groups I \& II.

\begin{tabular}{|c|c|c|}
\hline Groups & No gaps & Gaps \\
\hline Group I( exposed) & $7(28 \%)$ & $18(72 \%)$ \\
\hline Group II(control) & $22(88 \%)$ & $3(12 \%)$ \\
\cline { 1 - 1 } Z & & 4.29 \\
\cline { 1 - 1 } P & & $0.0001^{*}$ \\
\hline
\end{tabular}

$\mathrm{P}<0.05$ significant*.

Table (3): Number of cells with micronuclei among 500 cells analyzed for each individual.

\begin{tabular}{|c|c|c|}
\hline Groups & Group I( exposed) & Group II( control) \\
\hline $\mathrm{X}$ & 15.16 & 2.44 \\
\hline$\pm \mathrm{SD}$ & 4.45 & 1.99 \\
\hline $\mathrm{T}$ & \multicolumn{2}{|c|}{13.04} \\
\hline $\mathrm{p}$ & \multicolumn{2}{|c|}{$0.0001^{*}$} \\
\hline $\mathrm{X}:$ mean & SD : standard deviation. $\quad$ P 0.05 significant.
\end{tabular}


Table (4): Size of the comet tail in $\mu \mathrm{m}$ of 100 cells analyzed for each individual.

\begin{tabular}{|c|c|c|}
\hline Groups & Group I(exposed) & Group II( control) \\
\hline $\mathrm{X}$ & 36.38 & 26.25 \\
\hline$\pm \mathrm{SD}$ & 9.34 & 8.51 \\
\hline $\mathrm{T}$ & \multicolumn{2}{|c|}{0.74} \\
\hline $\mathrm{p}$ & \multicolumn{2}{|c|}{$003^{*}$} \\
\hline X: mean & SD : standard deviation. $\mathrm{P}<0.05$ significant
\end{tabular}

Table (5): Damage index in 100 cells analyzed for each individual in comet assay.

\begin{tabular}{|c|c|c|}
\hline Groups & Group I(exposed) & Group II(control) \\
\hline $\mathrm{X}$ & 18.08 & 2.23 \\
\hline$\pm \mathrm{SD}$ & 4.36 & 1.71 \\
\hline $\mathrm{T}$ & \multicolumn{3}{|c|}{16.9} \\
\hline $\mathrm{p}$ & 0.001 \\
\hline $\mathrm{X}:$ mean & \multicolumn{3}{|c|}{$\mathrm{P}<0.05$ significant } \\
\hline
\end{tabular}


Zaher, et al...

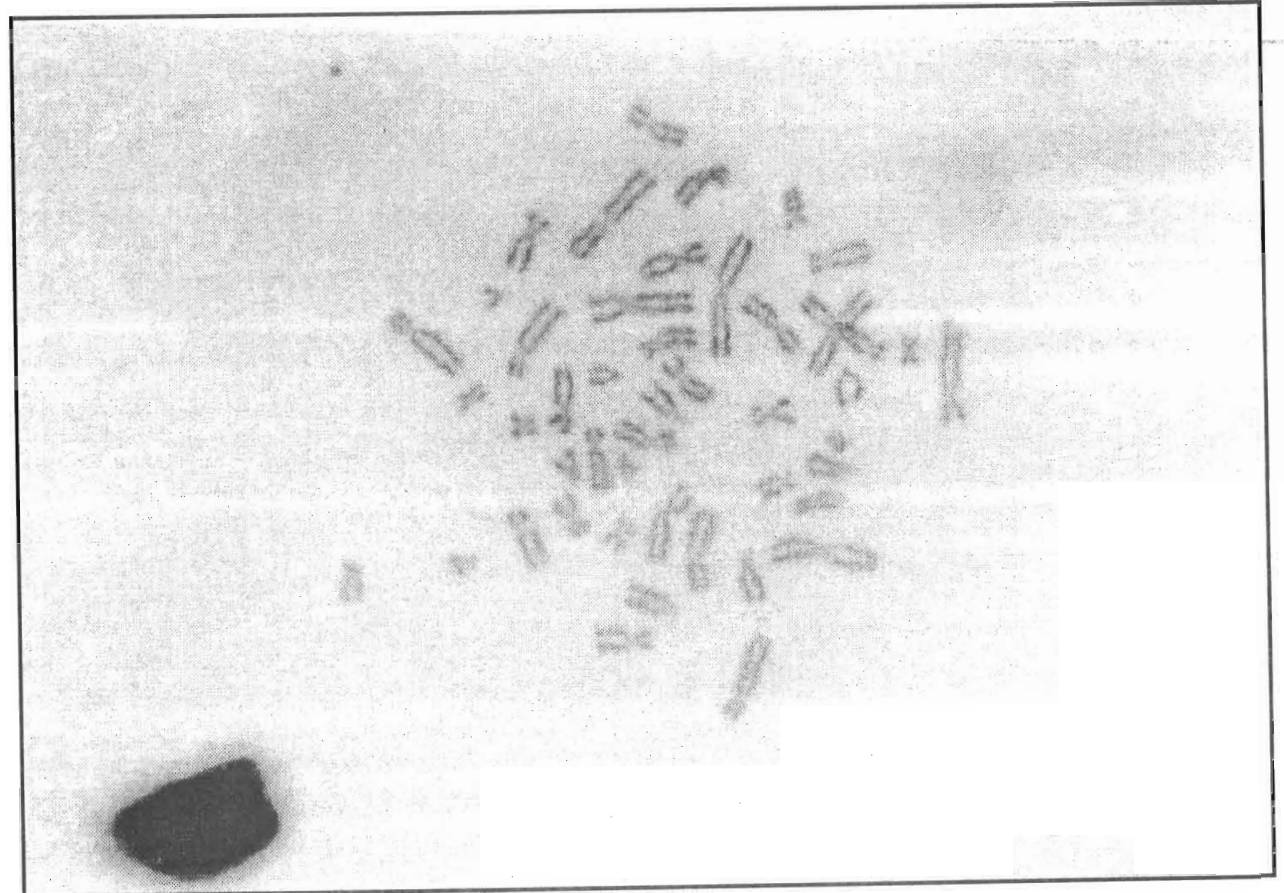

Fig. (1) : A photomicrograph showing normal chromosomal pattern of the control group (group II) stained by Giemsa stain (X 100).

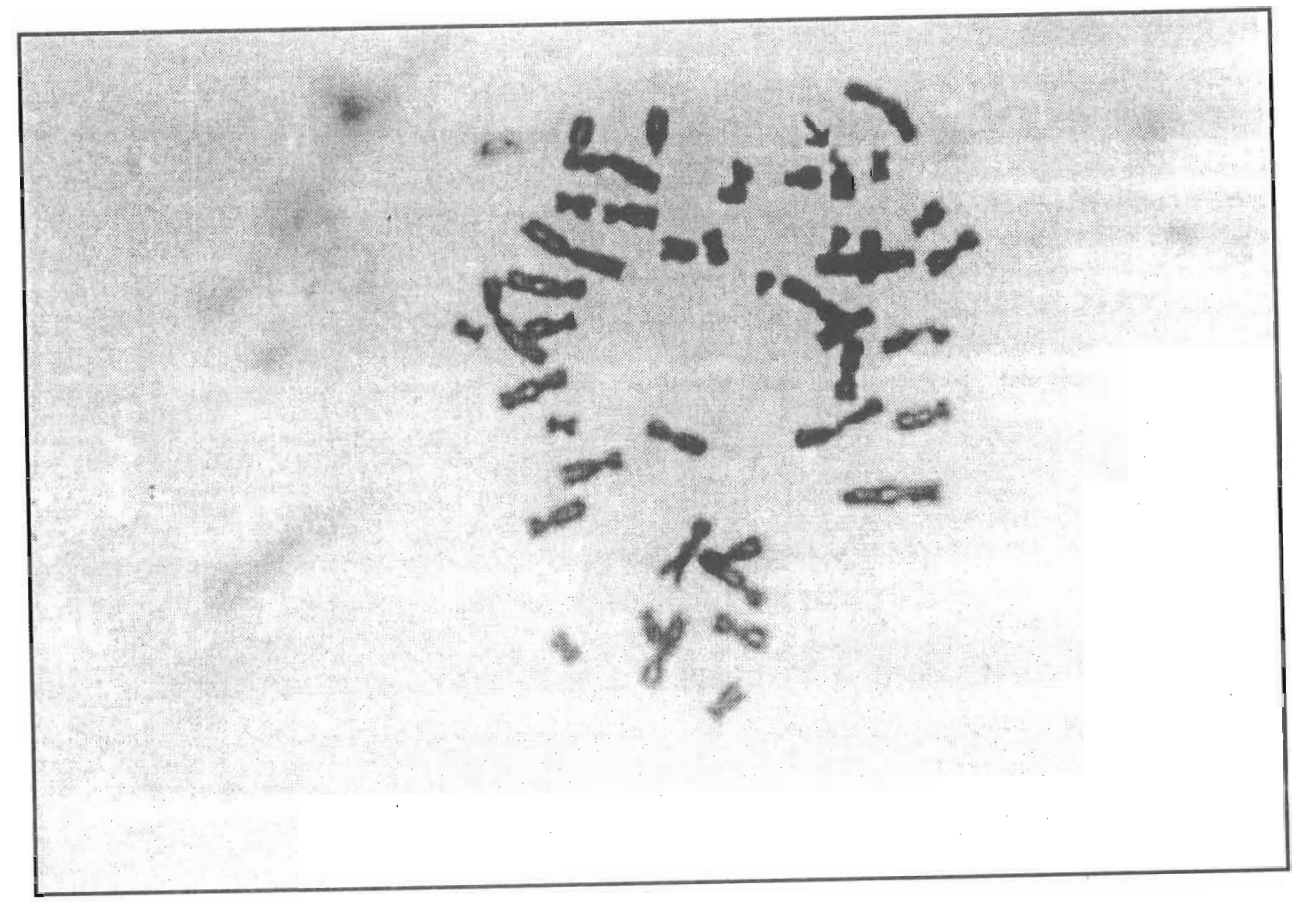

Fig. (2) : A photomicrograph showing chromosomal break in the exposed group (group I) stained by Giemsa stain (X 100). 


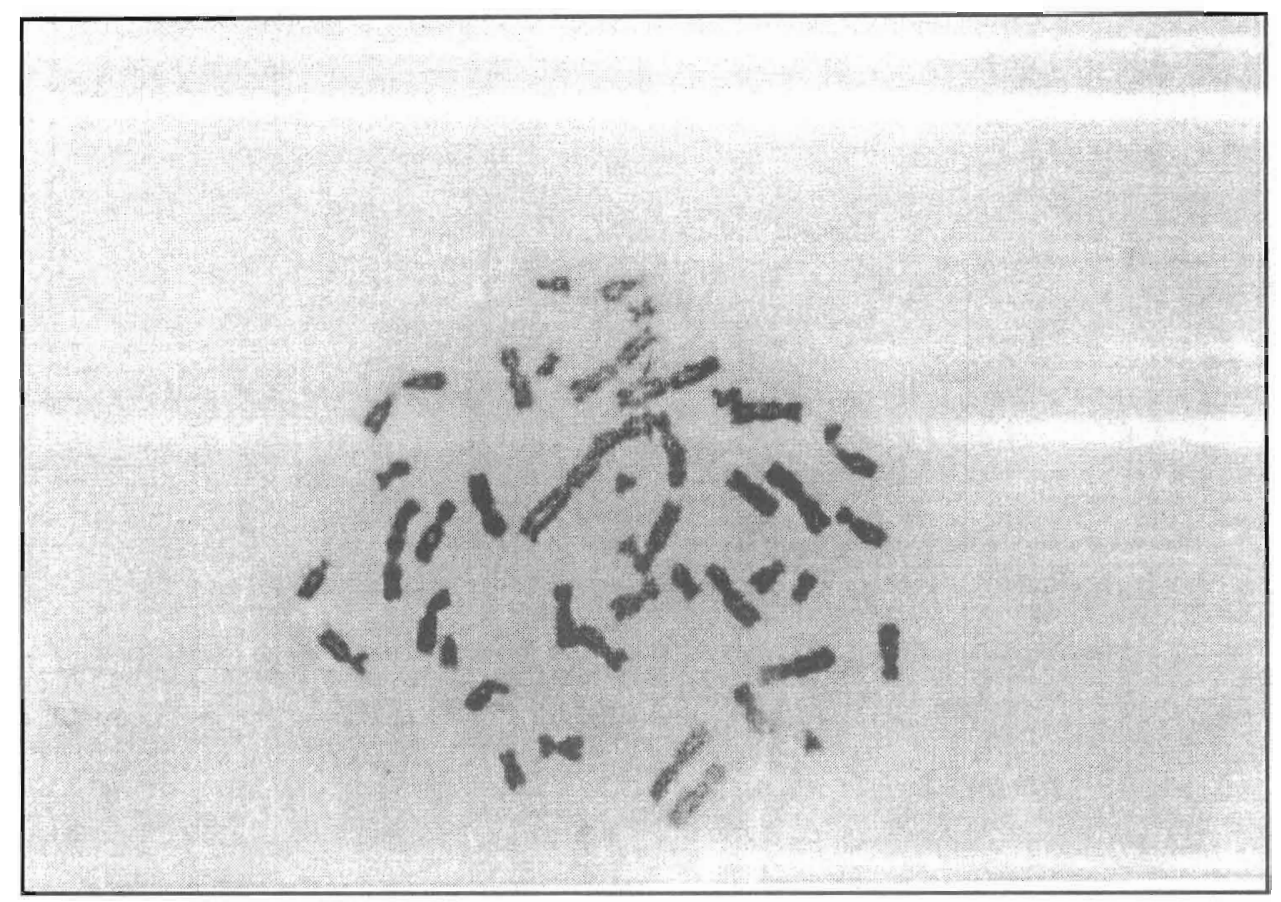

Fig. (3) : A photomicrograph showing chromatid gap in the exposed group (group I) stained by Giemsa stain. (X 100).

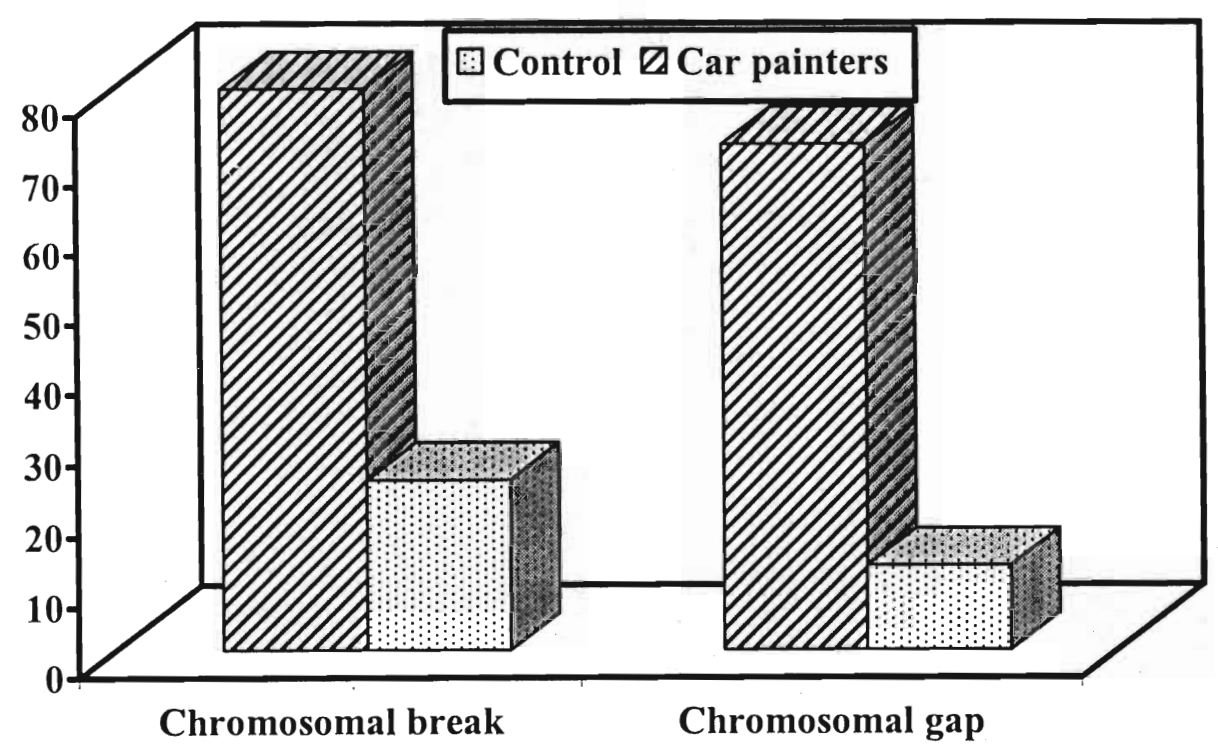

Fig. (4) : A histogram shows a comparison of the incidence of chromosomal breaks and gaps between exposed and control groups. 
Zaher, et al...

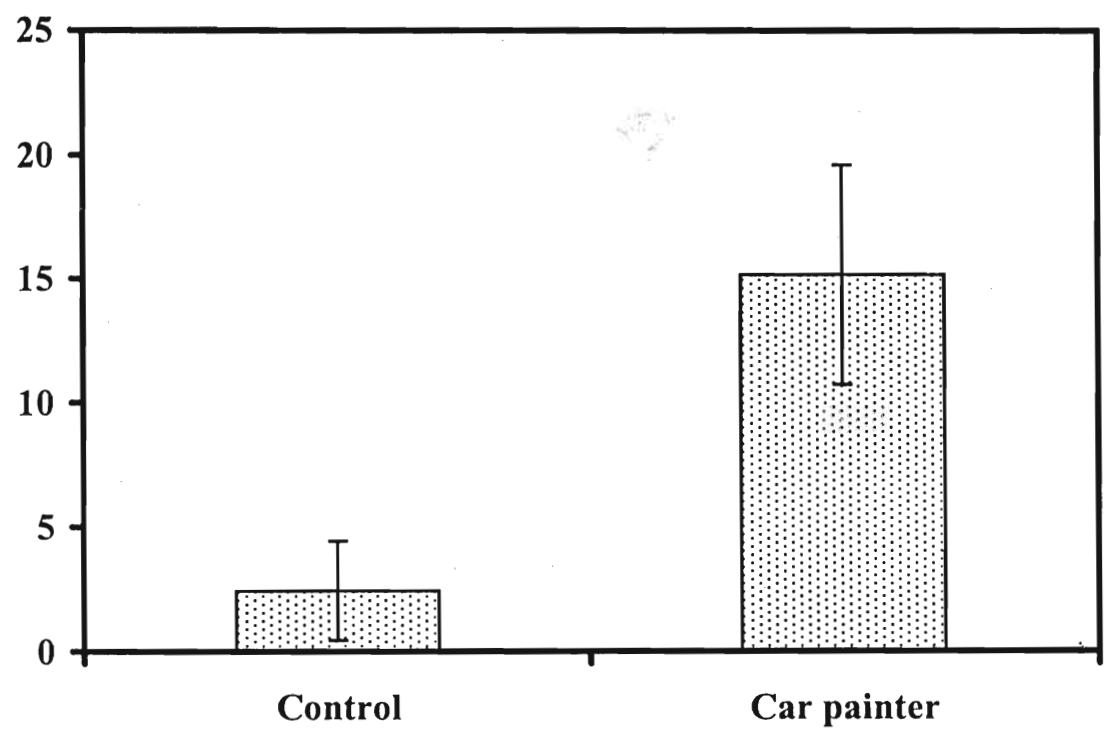

Fig. (5) : A histogram shows a comparison of the mean number of micronucleated cells between exposed and control groups.

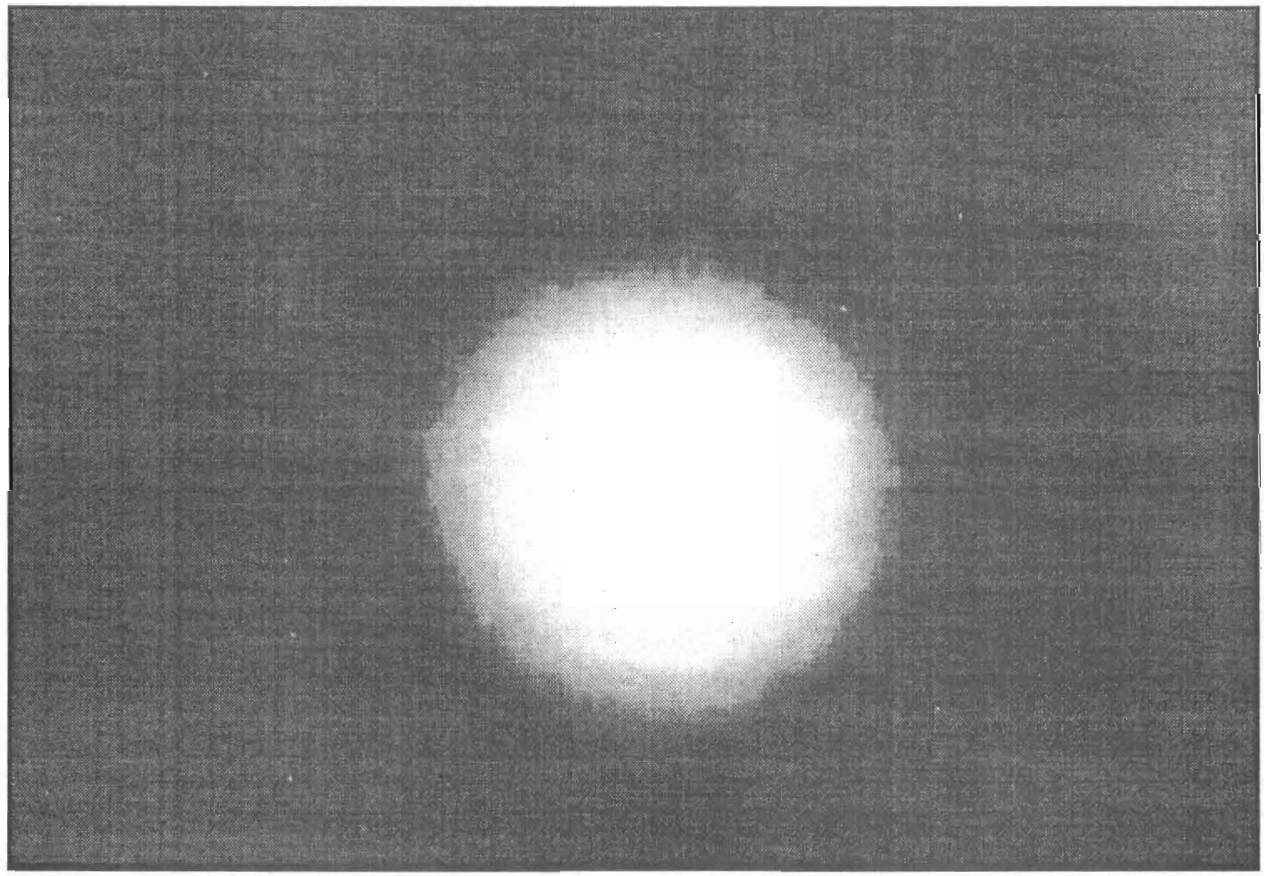

Fig. (6) : A photomicrograph showing class 0 (undamaged) score in comet assay examined by fluorescence microscope. (X 1000). 


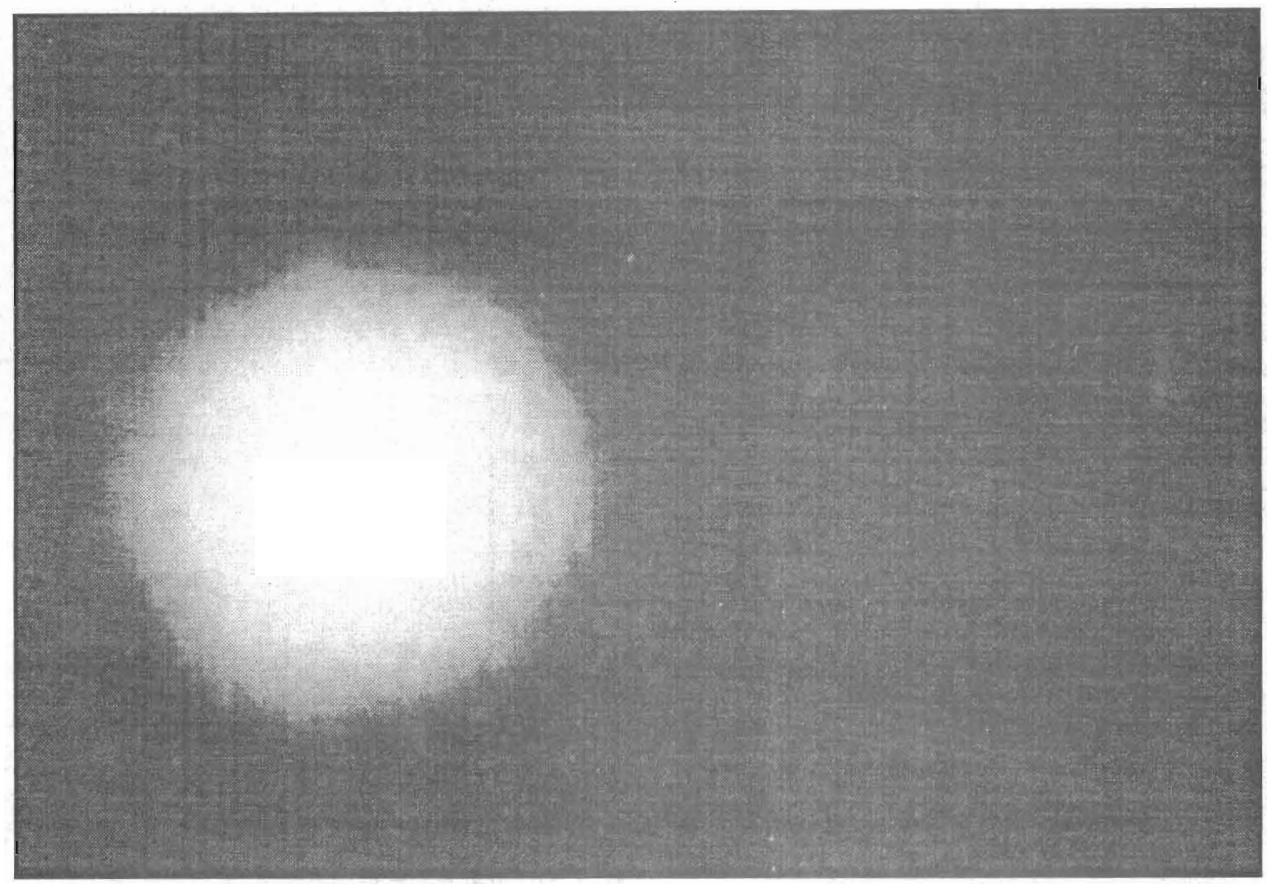

Fig. (7) : A photomicrograph showing class 1 score in comet assay examined by fluorescence microscope. (X 1000).

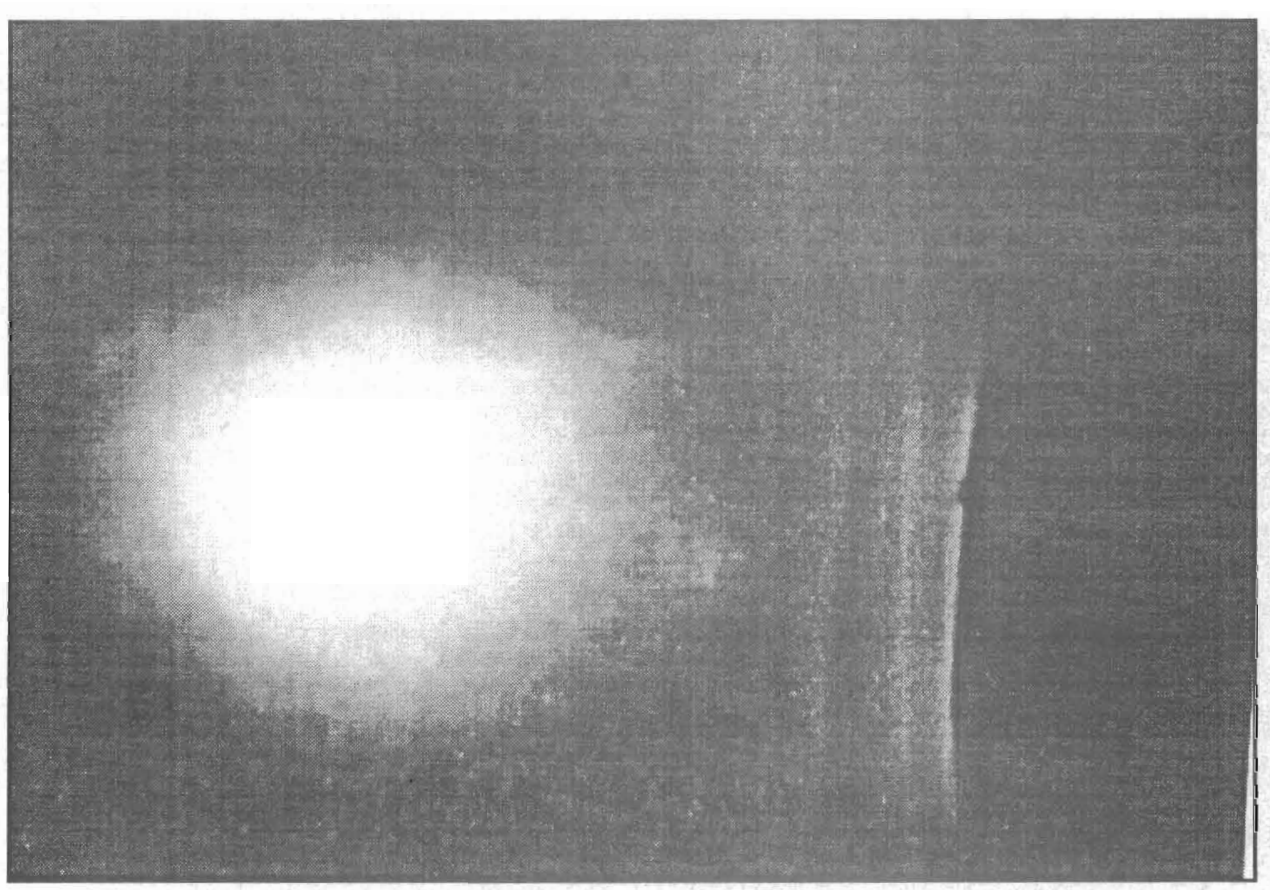

Fig. (8) : A photomicrograph showing class 2 score in comet assay examined by fluorescence microscope. (X 1000). 
Zaher, et al...

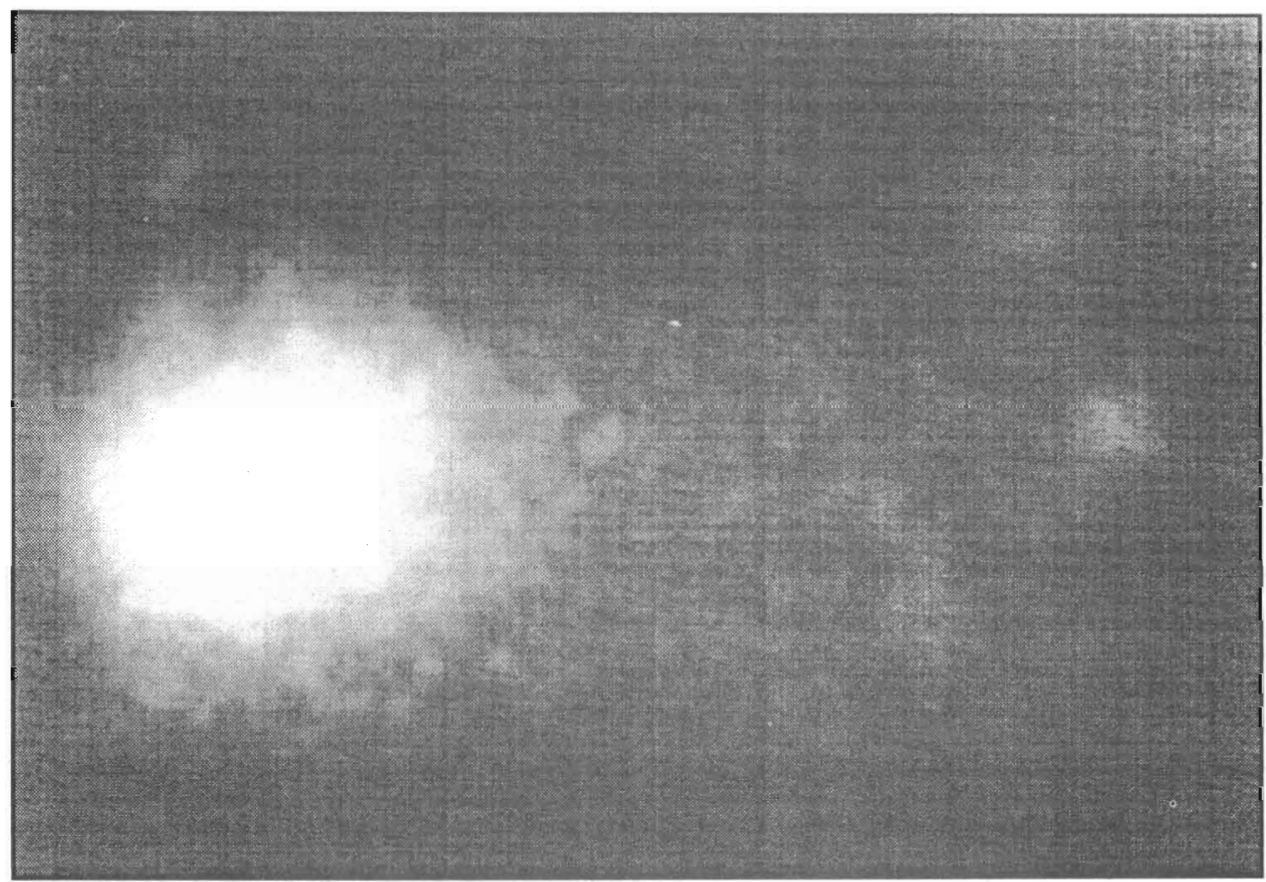

Fig. (9) : A photomicrograph showing class 3 score in comet assay examined by fluorescence microscope. (X 1000).

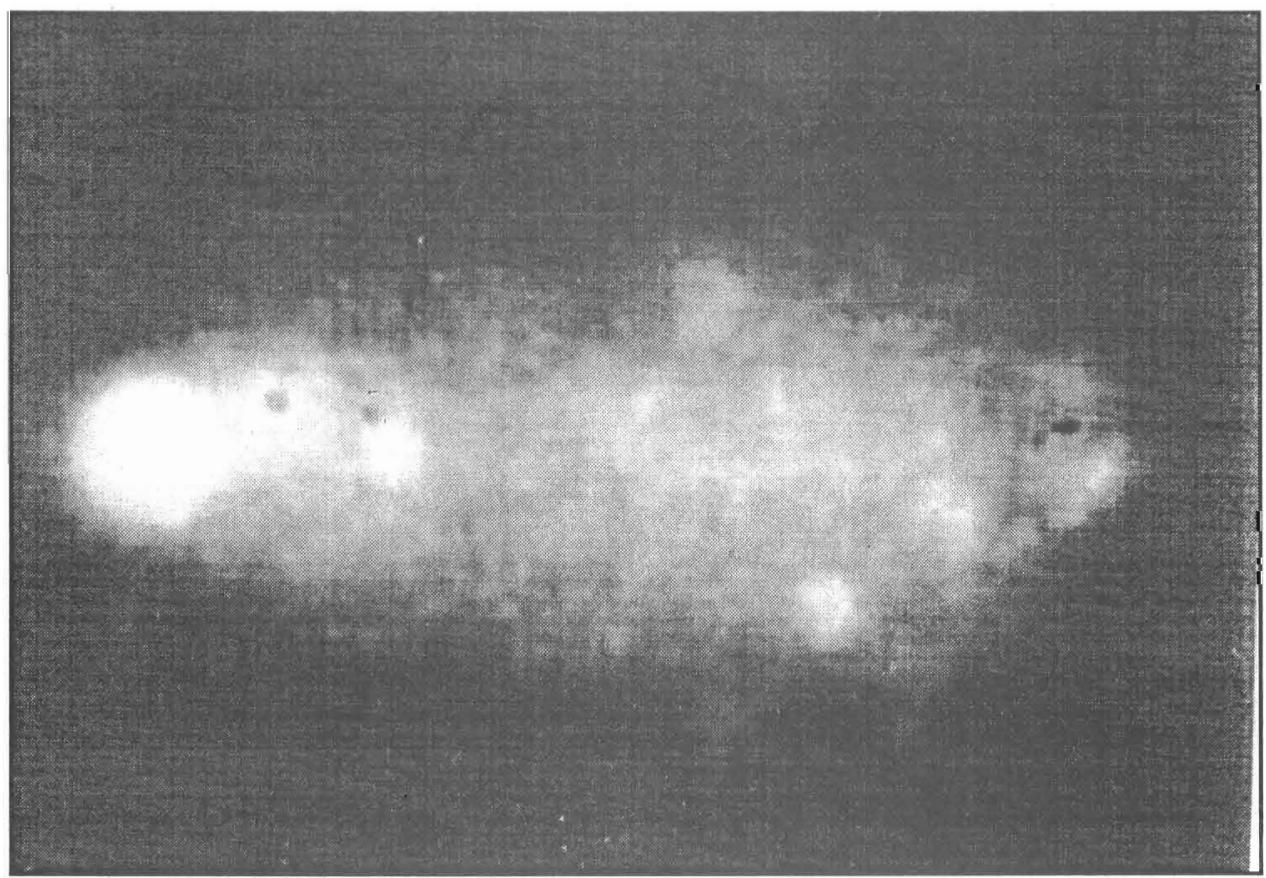

Fig. (10) : A photomicrograph showing class 4 (maximum damage) score in comet assay examined by fluorescence microscope. (X 1000). 
Zaher, et al...

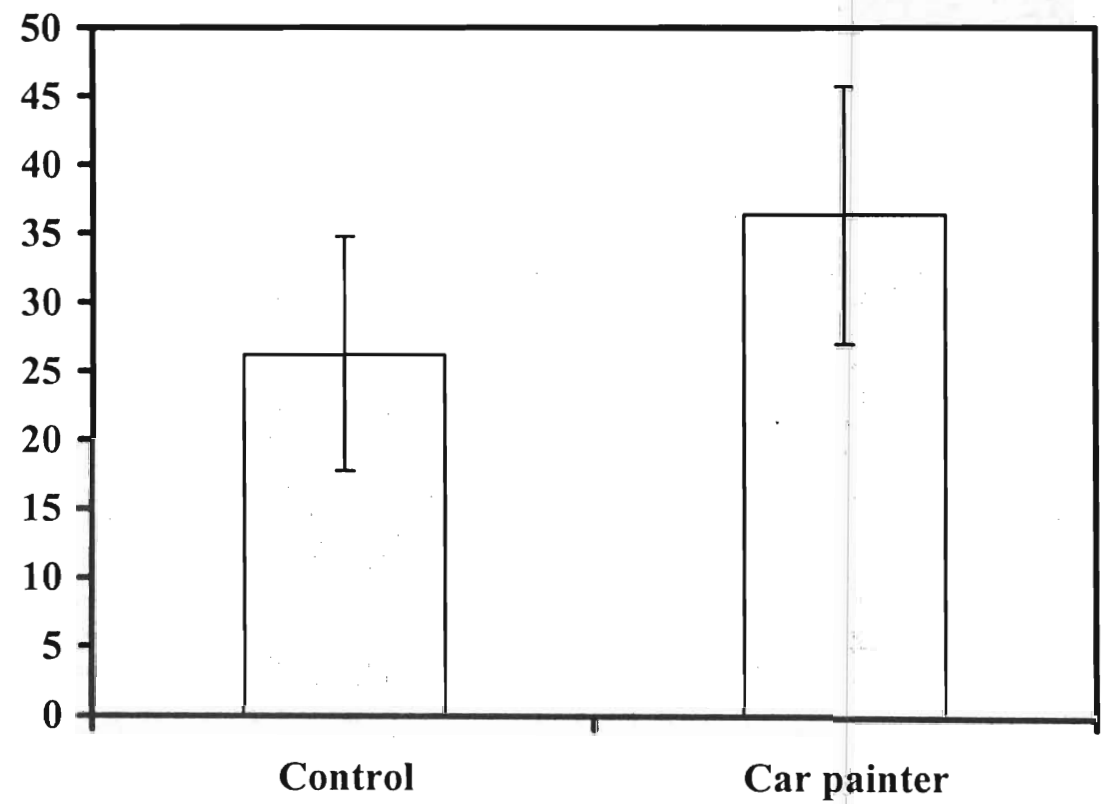

Fig. (11) : A histogram shows the mean size of the comet tail in exposed and control groups.

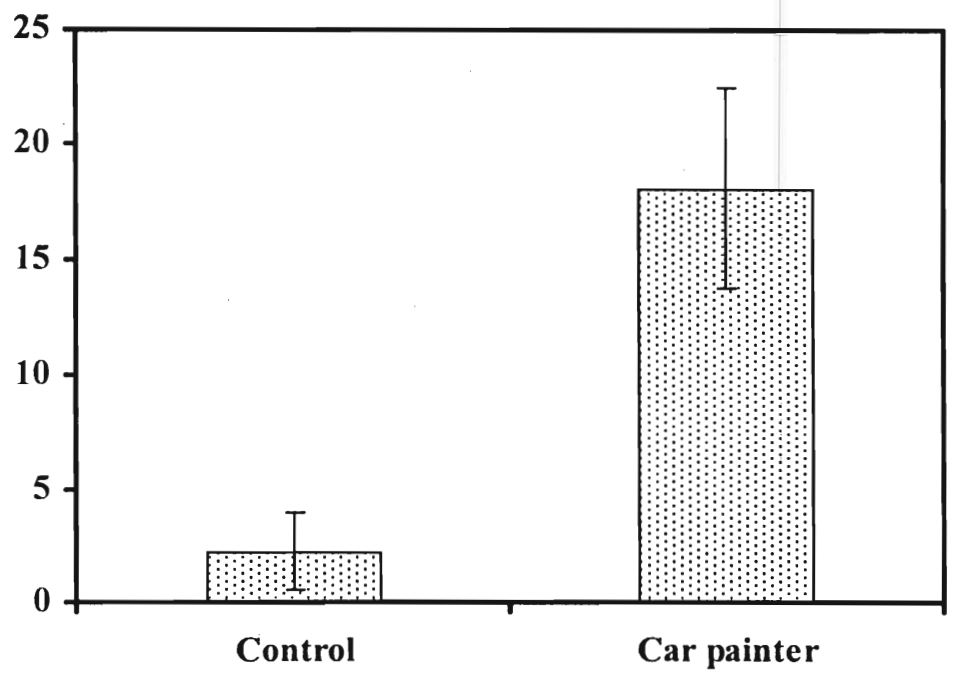

Fig. (12) : A histogram shows the mean of the damage index in the exposed and control groups. 


\section{REFERENCES}

Banjong, V.; Supaporn, J. and Pitchaya, T. (2005) : "Exposure to lead, cadmium and chromium among spray painters in automobile body repair shops". Journal of Occupational Health, 47:518-22.

Celi, K. A. and Akbas, E. (2005) : "Evaluation of sister chromatid exchange and chromosomal aberration frequencies in peripheral blood lymphocytes of gasoline station attendants". Ecotoxicol. Environ. Saf., 60(1):106-12.

Fucks, J.; Hengstler, J. and Oesch, F. (1996) : “Transient increase in DNA strand breaks in car refinishing spray painters. Scand". J. Work Environ. Health, 22 (6):438-43.

Hegmar, L.; Bonassi, S.; Stromberg, U.; Knudsen, L. and Norppa, H. (1998) : "Chromosomal aberrations in lymphocytes predict human cancer". Cancer Res., 58:4117-21.

Klaude, M.; Eriksson, J.; Nygren, J. and Ahnstrom, G. (1996) : "The comet assay: mechanism and technical consideration". Mutat. Res., 363:89-96.

Knudsen, L.; Norppa, H.; Camborg, M.; Nielsen, P. and Okkels, H. (1999) : "Chromosomal aberrations in humans induced by urban air pollution". Cancer
Epidemiology Biomarkers \& Prevention, 8:303-10.

Liou, S.; Lung, C.; Chen, W.; Yang, T.; Chen, C. and Wu, T. (1999): "Increased chromosome -type chromosome aberration frequencies as biomarkers of cancer risk in a blackfoot endemic area". Cancer Research, 59:1481-84.

Martino, M. G.; Viegas, J.; Amaral, M.; Oliveira, L. and Ferreira, F. L. (2002) : "Evaluation of genotoxicity through micronuclei test in workers of car and battery repair garages". Genet. Mol. Biol., 25 (4):415-21.

Martino, M. G.; Viegas, J. and Roth, D. M. (2003): “Occupational genotoxicity risk evaluation through the comet assay and the micronucleus test". Genet. Mol. Res., 2(4):410-17.

Nersesyan, A. K. (2005) : Letter to the Editor. Genet. Mol. Res., 4(2):174-6.

Norppa, H. (2004) : "Cytogenetic biomarkers". Int. J. Hyg. Environ. Health, 204(1):31-8.

Norppa, H. and Falck, G. (2003) : "What do micronuclei contain?" Mutagenesis, 18(3):221-33.

Pinto, D.; Ceballos, J.; Garcia, G.; Guzeman, P. and Vera, E. (2000) : 
"Increased cytogenetic damage in outdoor painters". Mutat. Res., 467(2):105-11.

Pitarque, M.; Vaglenov, A.; Nosko, M.; Pavlova, S. and Creus, A. (2002) : "Sister chromatid exchanges and micronuclei in peripheral lymphocytes of shoe factory workers exposed to solvents". Environmental Health Perspectives,110(4):102-9.

Silva, J. M. and Santos, M. M. (1996) : "Chromosomal aberrations in lymphocytes from carpainters". Mutat. Res., 368 (1):21-5.

Szyfter, K.; Szule, R.; Mikstacki, A. and Rydzanicz, M. (2004) : "Genotoxicity of inhalation anaesthetics: DNA lesions generated by sevoflurane in vitro and in vivo". J. Appl. Genet., 45:369-74.

Testa, A.; Festa, F.; Ranaldi, R.; Giachelia, M.; Marco, A. and Cozzi, M. (2005) : "A multibiomarker analysis of DNA damage in automobile painters". Environ. Mol. Mutagen, 46(3):182-8.

Tuimala, J.; Szekely, G.; Wikman, H. and Norppa, H. (2005) : "Genetic polymorphism of DNA repair and xenobiotic metabolizing enzymes". Mutat. Res., 570 (2): 203. 


\section{الدلالت الهيوية للتأثير الوراثى الضار فى العاملين بههنة طلاء السيارات}

$$
\text { المشتركون فى البحث }
$$

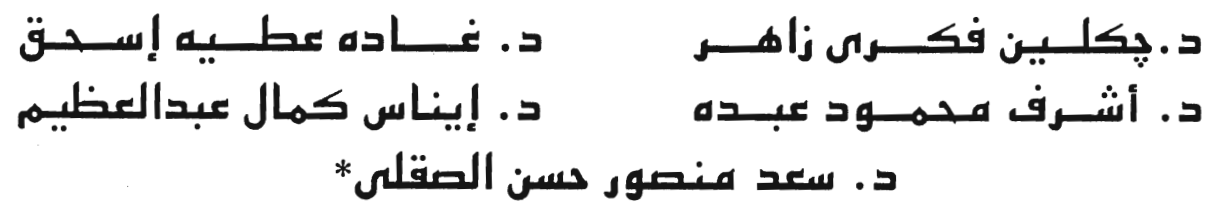

من أقسام الطب الشرعى والسموم الإكلينيكية والكيمياء* - كلية الطب - جامعة المنيا

أجريت هذه الدراسة لتحديد الدلالات الحيوية الدالة على التأثير الوراثى الضار الذى ينتج عن التعرض المهنى لكثير من المواد الكبميائية المتوافرة بواد الطلاء بالنسبة للعمال الذين يعملون فى مهنة طلاء السيارات.

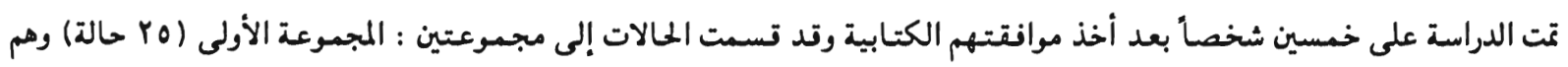

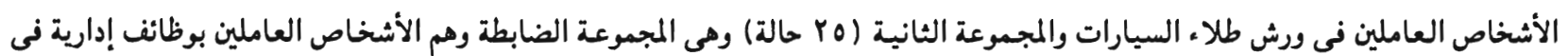

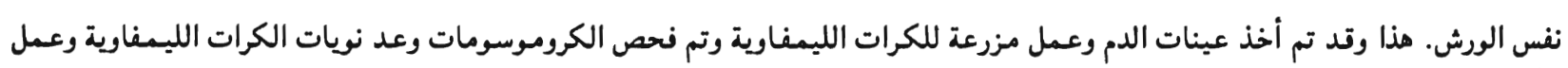
فحص كومت.

وتد أظهرت الثتائج وجود زيادة ذات دلالة إحصائية فى أنواع مختلفة من العيوب بالكروموسومات وفى عدد نويات الكرات الليمفارية

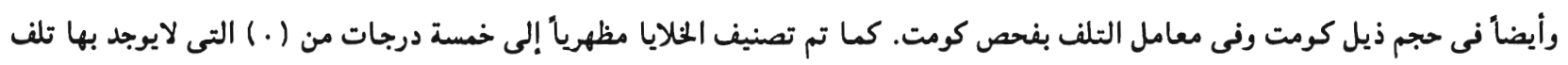

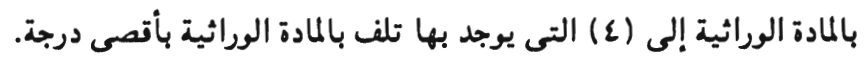
وتـد أستخلصت الدراسة أن تعرض العاملين بمهنة طلاء السيارات أثناء عملهم برش السيارات لمختلف المواد الكيميائية يؤدى إلى تأثير

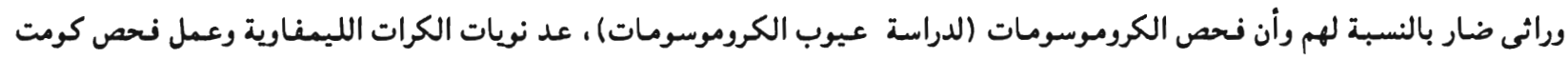

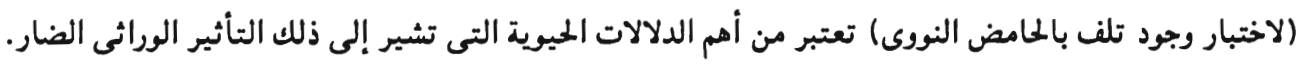


